Електронне наукове фахове видання "Ефективна економіка" включено до переліку наукових фахових видань України з питань економіки

(Наказ Міністерства освіти і науки України від 29.12.2014 № 1528) www. economy.nayka.com. ua | № 4, 2019 | 26.04.2019 p.

DOI: $\underline{10.32702 / 2307-2105-2019.4 .47}$

УДК 330.15

\author{
L. S. Otroshchenko \\ Ass. Professor, Sumy State University \\ A. A. Proshunina \\ student, Sumy State University
}

\title{
THE PHENOMENON OF "EXTERNALITIES” AS MARKET FAILURES
}

\author{
Л. С. Отрощенко, \\ дои., к.п.н., Сумській Державний Універсітет \\ А. А. Прошуніна, \\ студентка, Сумській Державний Універсітет
}

\section{ЕКСТЕРНАЛЇ ЯК ЗОВНІШНІ ЕФЕКТИ РИНКОВИХ ЗБОЇВ}

At the beginning of the 21st century we experience the situation, which can be described as "the green boom" or "green madness". This situation caused the opening of the new bigger discussion about the theme of externalities. Today, we live in a world that is strongly interconnected. This causes not only benefits, but also new difficulties.

Externalities are part of the economy, life and society in general. Economically and politically, they are the result of market and government failure. Externality arises when one entity benefits, and other entities bear the cost without being compensated. In this case, negative externalities are considered.

So the environment has recently been - and not only by the influence of externalities - brought to the forefront of the interest not only of ecologists but also of economists. Today we can even talk about environmental economics. More and more space, both in politics and in the media, is devoted to "green" issues. There is a transformation of ecological groups into a political party and through them ecology directly affects society and the economy.

Various solutions of economic and ecological problems are being implemented. These solutions are mostly a combination of legislative, economic and technical measures. In the tax systems of many countries, so-called green taxes are being adjusted. This is in particular the imposition of excise duty on fossil fuels. These taxes are explained by efforts to reduce the consumption of non-renewable raw materials. Some countries are taking a tax incentive for ecological behavior. Whatever these measures are called, it is essentially about solving the problem of externalities through economic policy.

Although some examples in the theoretical part might seem to be the problem of externalities as a problem for two or more individuals, it is necessary to realize that the problem of externalities is also a problem of the environment, especially in the case of transport. Although many authors (Coase) reject externalities as moral, this aspect can not be denied either. Therefore, the theoretical part of this work reacts, albeit marginally, to the moral dimension of externalities. 
На початку 21 століття ми відчуваємо ситуацію, яку можна назвати «зеленим бумом» або «зеленим безумством». Така ситуачія спричинила відкриття нового великого обговорення теми екстерналій. Сьогодні ми живемо в світі, який міцно взаємопов'язаний. Це викликає не тільки переваги, але й нові труднощі.

Екстерналії $\epsilon$ частиною економіки, життя $i$ суспільства в цілому. $B$ економічному та політичному планах вони є результатом ринкових збоїв. Екстернальність виникає тодi, коли суб'єкт господарювання отримує вигоду, а інші суб'єкти несуть витрати без компенсації. У изьому випадку розглядаються негативні екстерналіі.

Отже, навколишнє середовище нещьдавно вивело на перший план інтерес не тільки екологів, але і економістів. Сьогодні навіть можна говорити про економіку навколишнього середовища. Все більще $i$ більще часу, як у політиці, так $i$ в засобах масової інформації, присвячено «зеленим» питанням. Відбувається трансформація екологічних груп у політичну партію $і$ через них на екологію безпосередньо впливають суспільство та економіка.

Реалізуються різні рішення економічних та екологічних питань. Ці рішення в основному $\epsilon$ комбінацією законодавчих, економічних і технічних заходів. У податкових системах багатьох країн коригуються так звані зелені податки. Це, зокрема, запровадження акцизного збору на паливо. Ці податки пояснюються зусиллями щьодо зменшення споживання невідновлюваної сировини. Деякі краӥни беруть податкові стимули для екологічної поведінки. Якими б не були названі ці заходи, це, по суті, рішення проблеми зовнішнього впливу через економічну політику. Хоча деякі приклади в теоретичній частині можуть здаватися проблемою зовнішніх ринкових збоїв як проблеми для двох або більще осіб, необхідно усвідомити, щуо проблема зовнішнього впливу також є проблемою навколишнього середовища, особливо у випадку транспорту. теоретична частина цієї роботи реагує, хоча $i$ незначно, на моральний вимір зовнішніх чинників, також.

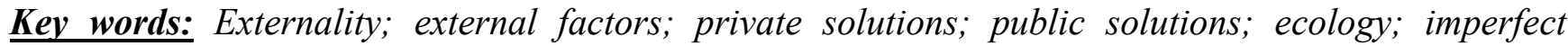
information.

Ключові слова: Екстерналї; зовнішні чинники; приватні рішення; публічні рішення; екологія; недосконала інформація.

\section{Problem statement.}

The subject of investigation has been chosen because of vital importance of environmental pollution protection and no doubt in the last few years ecology has become a "trend" for modern society. More and more businesses are focusing on organic production, which is, in our opinion, a big step forward for future generations. Since the 1960s economic theory has been dealing with areas such as externalities, public goods, spillovers, etc [3, p. 25]. The most important of these phenomena are the externalities as positive or negative consequences of an economic activity, which were already mentioned and are the subject of our research.

Analysis of recent research and publications.

The notion "externalities" and their influence on economy and society broadly have been thoroughly examined by many Ukrainian and foreign scientists, scholars and economists. It should be mentioned that the background of this term was firstly presented by English economist Arthur Cecil Pigou in his book "The Economics of Welfare" in 1920. Then in 1958 American economist and Nobel Prize laureate Paul Samuelson introduced word combination "external effects". Further this phenomenon was studied by R. Coase (1960), J. Buchanan (1962), K. Arrow (1973), Heller and Bartlett (1976), C. Dahlman (1979), R. Barro, J. Lee (1994), I. Malỳ (1998), R. Frank, B. Bernanke (2003), R. Holman (2005), Čadil (2006), A. Tomová (2006), B. Duchon (2010) (2006) and others. Recently this subject has been studied by N. Solomianiuk (externalities in marketing) [2], I. Radionova, N. Tkachenko (externalities in education) [1], M. Sorokivska (externalities influence on national economy efficiency), O. Omelchenko (informational externalities).

Formulating the aim of the article.

In our opinion, the question of negative externalities influence on economy and ecology and the ways out to minimize it has been not enough studied. That's why the main purpose of this work is to describe and to analyze in detail 
the causes of externalities and to focus on their possible benefits for society and the possibilities how to deal with their negative consequences or how to prevent them.

\section{Main material content.}

To start with we would like to present forms of market failure. Undoubtedly, in the real economic environment, there are many obstacles to perfect competition and a large number of reasons for the existence of market failures. In general, these forms of market failure can be divided into four basic groups:

- monopoly power;

- externalities;

- public goods;

- imperfect (asymmetric) information.

We will now look at the different forms of market failures, characterize all of them briefly and give some examples.

Speaking about the monopoly power, we should point out that it is the only producer, who determines the price of production. The absence of substitutes and strong barriers mean an exclusive market position. The greater the monopoly power, the lower the price elasticity or the greater the monopoly power, the more difficult it is to lower the price and the consumer must accept the market, even if prices are overpriced. The monopoly must also know the needs of its consumers and their willingness to pay for the products.

Other form of market failures are public goods. This concept is very misleading, because it is already calling us to the idea of public ownership.

We would like to present the determination of public goods as "goods, from the consumption of which cannot be excluded a consumer, who does not pay for them". The second property of public goods is incompatibility, so-called nondiminishing. This means that the arrival of marginal consumer does not limit the consumption of other consumers. So if these goods already exist, any consumer can use them freely and do not pay for them because their owner is not able to choose a fee for their use. This is that happens to the so-called black passer. This means that the producers are not able to finance the sale or lease of these goods.

As for imperfect (asymmetric) information, this situation occurs when one side of the market knows more than the other one. On the one hand, the information is more complete and, on the other hand, the information is incomplete. One of market sides is therefore disadvantaged (the seller knows more than the buyer about the quality of the product sold, the company knows more about the market conditions of its rivals than they themselves, the managers know more about the company than its owners, etc.).

In our opinion, asymmetric information arises from two consequences:

- hidden activity - an activity that cannot be observed accurately and without significant additional costs with other entities.

- hidden information - a situation in which one market side has more knowledge than the other one.

As our objective was the study of externalities, we will investigate this phenomenon in detail. Externality arises when someone does not bear the full cost of their activities or if they do not get the full revenues of their activity. "More specifically, externality is a certain impact of one economic entity's behavior on the well-being of another entity, and this impact is not reflected in market transactions or in dollars" [3, p.124]. the future".

The problem of externality is, inherently, a problem of concern for future generations, the so-called "concern for

World literature even talks about the imperative of worrying about the future. "Simply, we must not continue to devalue our environment - we must not consume our capital. Sticking to this rule, the present generation should do everything to compensate future damages. If not - future generation will be forced to repay the cost of these damages. We are talking about the phenomenon of intergenerational externalities".

The reasons for focusing on "natural resources" in "protecting the future" are as follows:

- the current damage to nature has too big consequences;

- while human capital is infinitely reproducible, natural capital often vice versa (the impossibility of substitution of natural capital);

- uncertainty.

For this reason, it turns out to be an unacceptable to approach consuming of natural capital only in terms of economic benefits and costs. Presently, at least conservation of the natural capital is held at the level that is necessary for our survival.

It can be noticed that some solutions of the most troublesome problems, have results. For example, it happens in case of an improvement in the ozone layer. The worldwide ban on the production of freons has positively influenced the ozone layer condition [5, p. 288].

In general, externalities are divided according to their characteristics into two main groups (or forms):

- negative externalities;

- positive externalities. 
As for negative externalities, they can be caused by any transformation. "Leaders" can be, for example, economic activity, production, or consumption. In the process of converting inputs into outputs, residual substances produced, can damage the environment and the people themselves in a large number of cases. As residual substances once occur, they begin to be stored in natural resources and spread gradually throughout the space. The following concentration of residues produces potentially negative impacts on the ecosystem, including its economic subsystems (if they cannot be completely eliminated). As Wang and Nijkamp [9] have said, this process of dissemination can take various forms and create different conditions for policy making. The most famous cases are one-way and multilateral cross-border pollution.

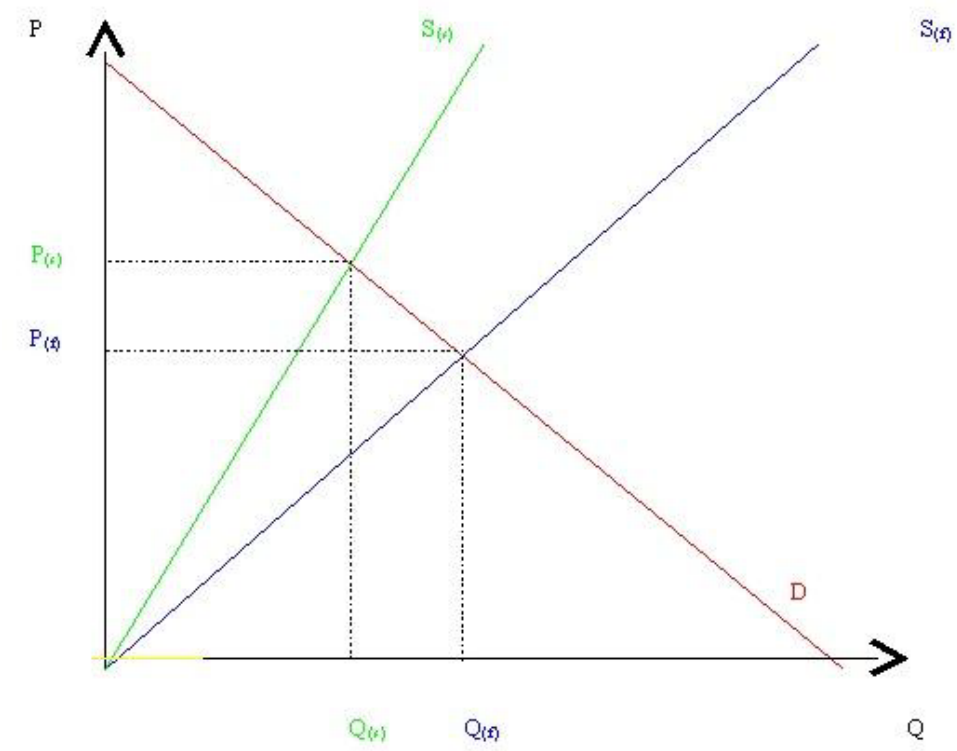

Pic. 1. Negative externality (graph)

$\mathrm{D}$ - demand for a good that is associated with negative externalities (i.e. consumer benefits).

S (f) - "private" offer of a good that is associated with a negative externality (i.e. without additional costs of third parties caused by the production).

S (s) - A "social" offer of a good associated with negative externalities (including extra costs of third parties caused by its production - that includes all social costs for the production).

Q (f) - the quantity of the good associated with negative externalities marketed by firms for their production (sale) price $\mathrm{P}(\mathrm{f})$.

Q (s) - the "socially optimal" quantity of the good that is associated with the negative externality, for its full (social) production price $\mathrm{P}(\mathrm{s})$.

In the second group of externalities - positive externalities, which we can simply define as: "A situation where the activity of one entity is beneficial to another subject and the costs associated with it do not have to be paid." On the Pic. 2 we can see that the socially optimal amount of the farm Q (s) is higher than Q (f) produced by firms, as companies do not include in their calculations the external yields of other members of the company. The socially optimal amount can be achieved by so-called internalizing of these external revenues, which will be reflected in the decision making of the producers [4, p.155]. 


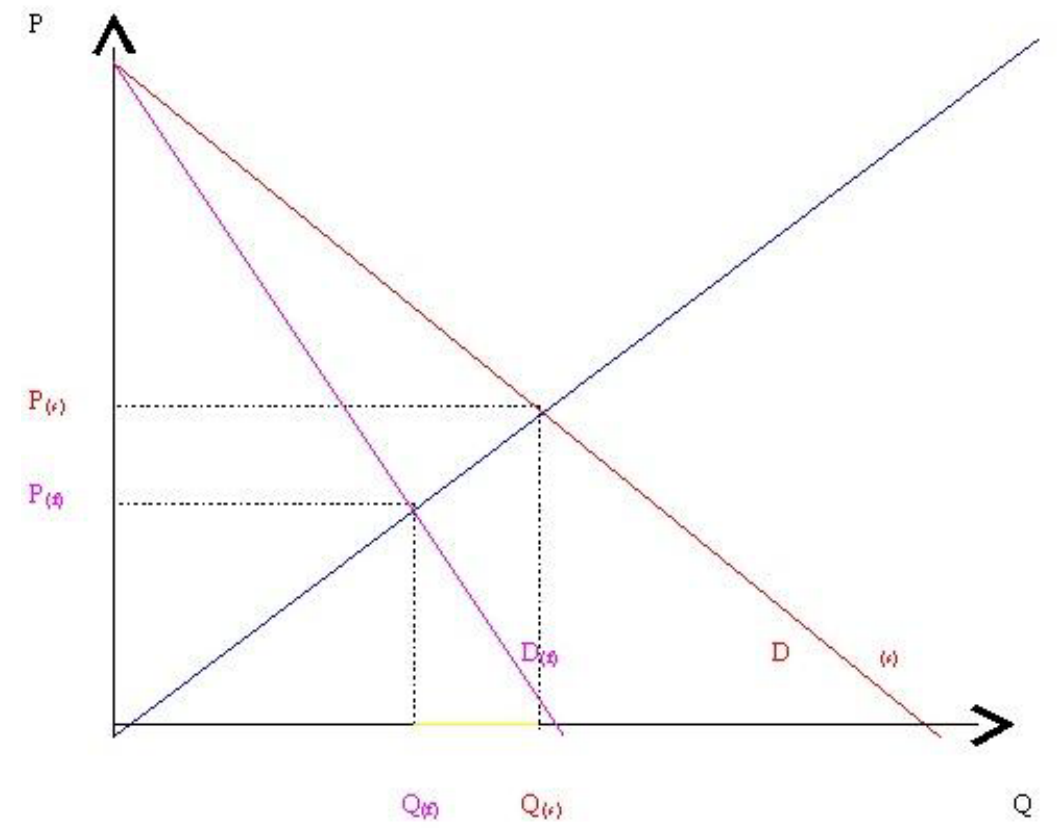

Pic. 2. Positive externality (graph) producer)

D (f) - "private" demand for goods that is associated with a positive externality (i.e. the marginal benefits of its

D (s) - "social" demand for a good that is associated with positive externalities (i.e. the marginal benefits that all members of society have from its existence).

$\mathrm{S}-$ the offer of the goods.

Q (f) - the quantity of the goods associated with the positive externality produced by the producer for his own benefit (for the price $\mathrm{P}(\mathrm{f})$ ).

Q (s) - the "socially optimal" quantity of the goods that is associated with the positive externality (for P (s)).

Speaking about the impact of negative externalities on the environment, we can say that the most common representatives of traditional pollutants of the basic components of the environment are primarily all actors and factors that devalue (pollute) air, water and landscape. Most often it is either industrial and agricultural factories including transport, but we also include ordinary activities of citizens such as tourism, recreation, transport, accommodation, meals, etc.

Let's observe this issue in case of transportation externalities.

In terms of costs, quantification of externalities in transport can be made using average or marginal costs. Investigations may also be made before or after the occurrence of externalities. It is important to evaluate the external costs of transport for comparable external evaluations in order to maintain comparability. In order to maintain the objectivity of the survey, it is also necessary to exclude from the evaluation subjective views on transport externalities. It is advisable to combine different solutions and choose optimal solutions [8, p.142]. Research on externalities is undergoing constant change. There has been a shift in externalization research methodology.

Consequently, modern research is more detailed. It distinguishes externalities caused by specific categories of vehicles. These studies, which are mostly funded from public sources, yield concrete conclusions for practical application in transport. Political decisions can be made on the basis of the price system. Pricing system is mostly linked to taxation (for example, a system of excise taxes on fuel, road tax, tolls) or direct transport by state-owned enterprises or to direct or indirect financial support to the preferred transport system. Such subsidies include, for example, operating grants, subsidies dependent on the number of persons transported, discounts for different groups of passengers, such as students, seniors or the disabled.

It is clear that public funds are not primarily intended to eliminate externalities in transport. However, public support makes public transport more cost-effective and, therefore, more competitive. In this case, there is a positive externality in that people using public transport do not burden the often overloaded communications. According to A. Tomova, total external costs in European countries are about $7.8 \%$ of GDP, accounting for about 530 billion euros, $90 \%$ of $[8$, p.96] these externalities causing road transport $[10$, p.76].

Traffic accidents are part of external freight costs. Like other external costs, road accidents are hardly quantifiable. The advantage of quantification of externalities caused by traffic accidents is the fact that detailed statistics is reported. From the financial point of view, it is interesting to discuss insurance companies [8, p.202]. Actual external costs can not be 
estimated accurately. It is also a matter of valuing human health and life. For this reason, the external costs of traffic accidents, expressed in money, are quite controversial. The vast majority of road accidents are accidents in road transport.

While the number of traffic accidents and the number of injured and killed persons in transport are well-known, the monetary expression of the consequences of traffic accidents is only an estimate. Expressing the value of human life and health in money raises a number of questions.

However, the emergence of negative externalities can be prevented in several ways. We will now introduce a few of them:

- Information and transaction costs;

- Marketable emission permits;

- Social sanctions;

- Gentle Technologies and Ecosystems;

- Property rights;

- Legal Standards.

No doubt, these measures are seen as a combination of legislative, economic and technical measures.

We would like to specify the possibilities of solutions in case of transport externalities.

A number of measures in order to identify quantify and eliminate undesirable external freight costs have been taken in the past years. A methodology for quantifying external freight costs has been developed and adopted.

In the area of taxes, consumer and road taxes are mainly responding to the negative effects associated with transport. A toll system on motorways has been introduced and is being considered to extend it. In the technical field, it invests in intelligent traffic management systems. Investment in transport is growing, resulting in an improvement in the state of the infrastructure and consequently a positive impact on the external area of transport. Technical developments in the field of vehicle construction and tighter legislative conditions for their manufacturers bring results, both in terms of energy intensity and emissions in transport and in terms of transport safety.

Generally, there are two opposing tendencies. These are, firstly, the pressure on growth in transport performance and the growth in the number of vehicles, and secondly, efforts to reduce transport as low as possible by legislation. It is not true that what is ecological can not be economical. It can be said that a whole industry that focuses on products that help reduce negative external transport costs is emerging. However, in the case of restrictions, economic, legislative and technical, the effectiveness of such measures must be carefully considered. It is necessary to monitor whether the costs (not only economic) that are spent on the removal of transport externalities do not cause economic inefficiency.

The main aim of this work was to describe the causes of externalities and to focus on their possible benefits for society and the possibilities how to deal with their negative consequences or how to prevent them.

The underlying cause of the existence of externalities is inaccurately defined property rights. Therefore, the existence of externalities can be addressed by a more precise definition and easier enforceability of property rights. Externality can not occur if ownership rights are formulated to fit the terms of Coase's theorem, which says that if one party is harming the other party and participants can negotiate without any additional transaction costs, they can effectively deal with negative externalities, regardless of, whether the law attributes responsibility for the unwanted costs of their work to people.

If it is not possible to negotiate without costs, then it is up to the lawful accountability.

Conclusions of research and prospects for further research.

As a conclusion we would like to say that, in our opinion, taxation is one of the possible solutions to the problem of negative externalities. Although it is not always an ideal solution, it offers many real advantages in a number of situations compared to direct regulation. Taxation of negative externalities is a source of government revenue, which largely eliminates inefficiencies disrupting optimal allocation.

In terms of this country European integration, prospects for further research related to this subject are seen in comparative analysis of other countries' experience of dealing with negative externalities and their prevention.

\section{References.}

1. Solomianiuk, N.M. (2014), "Theoretical definition of the concept of "externalities in marketing"", Ekonomichnyi forum, vol. 2, pp. 153-157.

2. Radionova, I. and Tkachenko, N. (2013), "Analysis of externalities in the educational sphere", Ekonomichna teoriia ta istoriia ekonomichnoi dumky, vol. 10 (148), pp. 36-44.

3. Čadil, Jan; Kadeřbaková, Boțena; Vorlíček, Jan. Analýza externalit, př́stup ekonomické teorie. 1. vyd. Praha: Česká zemědělská univerzita, 2006. - $157 \mathrm{~s}$.

4. Duchoň, Bedřich, aj. Teorie externalit a její aplikace v udržitelném rozvoji. 1. vyd. Praha: ČVUT, 2010. - $134 \mathrm{~s}$.

5. Frank, Robert H.; Bernanke, Ben S. Ekonomie. 1. vyd. Praha: Grada Publishing, 2003. - 804 s.

6. Holman, Robert. Ekonomie. 4. vyd. Praha: C. H. Beck, 2005. - 709 s.

7. Hořejší, Bronislava, aj. Mikroekonomie. 4. vyd. Praha: Management Press, 2006. - 574 s.

8. Malý, Ivan. Externality a možnosti jejich řešení. 1. vyd. Brno: Masarykova univerzita, 1998. - $195 \mathrm{~s}$. 
9. Wang, Shungli and De Groot, Henri L.F. and Nijkamp, Peter and Verhoef, Erik T., Global and Regional Impacts of the Clean Mechanism (May 25, 2009). Tinbergen Institute Discussion Paper 09-045/3. Available at SSRN: https://ssrn.com/abstract=1409593 or http://dx.doi.org/10.2139/ssrn.1409593 $-96 \mathrm{~s}$.

10. Tomová, A.: Finančná kvantifikácia externalít dopravy: metodické prístupy. Žilina: Žilinská univerzita, 2006.

\section{Literature.}

1. Соломянюк Н.М. Теоритичне визначення поняття "екстерналії в маркетингу"/ Н.М. Соломянюк// Економічний форум. - 2014. - № 2. С. 153-157.

2. Радіонова І., Ткаченко Н. Аналіз екстерналій у освітній сфері/ I. Радіонова, Н. Ткаченко //Економічна теорія та історія економічної думки. - 2013. - № 10 (148). С. 36-44.

3. Čadil, Jan; Kadeřbaková, Boțena; Vorlíček, Jan. Analýza externalit, přístup ekonomické teorie. 1. vyd. Praha: Česká zemědělská univerzita, 2006. - 157 s.

4. Duchoň, Bedřich, aj. Teorie externalit a její aplikace v udržitelném rozvoji. 1. vyd. Praha: ČVUT, 2010. - $134 \mathrm{~s}$.

5. Frank, Robert H.; Bernanke, Ben S. Ekonomie. 1. vyd. Praha: Grada Publishing, 2003. - 804 s.

6. Holman, Robert. Ekonomie. 4. vyd. Praha: C. H. Beck, 2005. - 709 s.

7. Hořejší, Bronislava, aj. Mikroekonomie. 4. vyd. Praha: Management Press, 2006. - 574 s.

8. Malý, Ivan. Externality a možnosti jejich řešení. 1. vyd. Brno: Masarykova univerzita, 1998. - $195 \mathrm{~s}$.

9. Wang, Shungli and De Groot, Henri L.F. and Nijkamp, Peter and Verhoef, Erik T., Global and Regional Impacts of the Clean Mechanism (May 25, 2009). Tinbergen Institute Discussion Paper 09-045/3. Available at SSRN: https://ssrn.com/abstract=1409593 or http://dx.doi.org/10.2139/ssrn.1409593

10. Tomová, A.: Finančná kvantifikácia externalít dopravy: metodické prístupy. Žilina: Žilinská univerzita, 2006. $-96 \mathrm{~s}$.

Стаття надійшла до редакиії 31.03.2019 p. 